African Research Review

An International Multidisciplinary Journal, Ethiopia

Vol. 9(1), Serial No. 36, January, 2015:73-94

ISSN 1994-9057 (Print) ISSN 2070--0083 (Online)

DOI: http://dx.doi.org/10.4314/afrrev.v9i1.7

\title{
Colonial Rule and Industrialization in Esan, Benin Province, Nigeria: A Case Study of Institutional Adaptation
}

\author{
Osagie, Joseph Inegbenebho \\ Department of History and International Studies \\ University of Benin \\ P.M.B. 1154, Benin City \\ Edo State, Nigeria \\ E-Mail: jiosagie@yahoo.com. \\ G.S.M. +2348056410713 \\ $\boldsymbol{\&}$ \\ Otoide, Leo Enahoro \\ Department of History and International Studies \\ University of Benin \\ P.M.B. 1154, Benin City \\ Edo State, Nigeria
}

\begin{abstract}
This paper examines the operation of British economic policy in Esan specifically as it relates to industrialization. Before the emergence of the British colonizers, the people of Esan were engaged in cottage industries which included cloth weaving (textile), basket and rope weaving, wood carving (art and craft), blacksmithing, pottery, soap and palm oil processing, palm wine tapping and food processing. The paper
\end{abstract}


argues that a traditional industrial structure and practice in Esan had attained a level of sophistication prior to the emergence of British who sought to impose new demands on society. The people as well as their institutions were not receptive to the new demands. Rather, there was a conscious effort to meet colonial expectations while at the same time formulating strategies that would accommodate the traditional practices. There was thus a continuous process of adjustments and search for relevance in the new economy that was imposed on the people of Esan by the British Colonial authorities.

Key words: Cottage Industries, Colonial rule, Institutional Adaptation

\section{Introduction}

From early times, Esan displayed a very dynamic response and initiative in harnessing the various natural resources in their environment. A basically agrarian society, Esan devised methods and techniques for making various articles or products which they needed from local resources. The process of production, even though was basically manual, was able to turn out manufactured goods for local consumption as well as exchange for goods which they needed but did not produce in sufficient quantities or not at all. There emerged in this manner some kind of household manufacturing engagements which were carried out either on part-time or full-time basis. These household engagements gave rise to the various cottage industries that thrived in Esan. It could be said therefore, that before the advent of the Europeans, cottage industries in Esan were very viable. Although the processes of manufacturing were crude and time consuming, the indigenous people were able to meet practically all their basic needs. They not only produced for consumption but had enough to sell or exchange for other items they needed. Had the situation been allowed to continue in this manner, it could have been possible for industrial growth and development to be achieved through innovations and specialisation.

The intention of the British towards indigenous industries was manifested at the very beginning of colonialisation of Esan and elsewhere in Nigeria. To them, encouraging local industries would have been a negation of the objective for which they came to Africa in the first place. It should be noted that the main objectives of the British and other European Powers in their quest for colonies was among others to provide outlets for their manufactured goods and obtain raw materials for their industries at home. So, they were not ready to expend their brain and resources to encourage and develop indigenous industries. According to Lord Lugard, one of the architects of colonial rule in Nigeria, “.... at the outset, European brains, capital and energy have not been, and never will be expended in developing the resources of Africa from the motive of pure philanthropy" (F.J.D. Lugard, 1965, p.512). 
The British authorities were therefore, not interested in the developing or improving the existing industries in her colonies. If any industry should be encouraged, it should only be in the area of improving the quality of raw materials to be exported from colonies and not that of manufacturing and industrial progress. Colonial industrial policies were therefore, not meant to improve the lot of the people but mainly to reduce waste and cost of shipment of the goods produced in the colonies. To the colonial authorities, this would in time promote commercial and industrial progress of colonies and their people. In the words of Lugard (1965):

our task is clear, it is to promote the commercial and industrial progress of Africa, with too careful scrutiny of the material gains to ourselves.... It has ...been our policy to encourage the export of raw materials, and to improve their quality, to promote trade and commerce, but not manufacture and industry (p.510).

This policy, instead of making the colonies strong and economically viable only subjected them to state of perpetual dependence on manufactured goods from Europe. To the British and their Allies, the colonies, with their fertile land and rich forest were only suitable for the production of raw materials and not for manufacturing. (Ibid.)

Esan (Anglicized Ishan, is one of the three major ethnic groups in Edo State of Nigeria. However, in the Nigerian context, it is a minority group - the main major ethnic groups being Hausa, Igbo and Yoruba. Esan is located between latitude $60^{\circ}$ and $90^{\circ}$ of the Equator and longitude $30^{\circ}$ and $35^{\circ}$ of the Greenwich Meridian. As at today, the Esan is constituted into five Local Government Areas namely; Esan West, Esan Central, Esan North East, Esan South West and Igueben. Pre-Colonial Esan, although cultural homogenous was politically fragmented with thirty-one autonomous kingdoms viz: Egoro, Opoji, Urohi, Irrua, Ewu, Uromi, Ugboha, Oria, Ubiaja, Udo, Okhuesan, Emu, Ohordua, Ewohimi, Ewosa, Ewatto, Ekpon, Ebelle, Okalo, Amahor, Ogwa, Ogun, Ujiogba, Ugbegun, Igueben, Ekehenlen, Orowa, Ukhun, Idoa, Ekpoma and, Onogholo. Each of these kingdoms was headed by a king - Onojie (pl. Enijie) (Bradbury, 1957, p.67; C.G. Okojie, p.11).

By 1900, the entire geographical region of what later became Nigeria was under the immense pressure of imminent collapse in the face of British incursion. The British had made significant inroads into the Nigerian hinterland and in 1897 the forest Kingdom of Benin had experienced a major military set back in her encounter with the British and this signalled a discomforting future for the outlying regions which bore close affinity with the Kingdom, including Esan. British "pacification" of Esan lasted for a decade as resistance was fierce and persistent. By 1910, save for patches of resistance in the region, the entire Esan area had succumbed to British rule. For effective administration, Esan was constituted into Ishan Division of Benin Province of Southern Nigeria. Benin Province with headquarters at Benin City was 
made up four divisions namely: Asaba Division, Benin Division, Ishan (Esan) Division, Kukuruku (Auchi) Division (B.P. 40/Vol. VI Annual Reports, 1937).

\section{Traditional industrialization in Esan and the challenges of British policy}

Esan people produced a variety of items in pre-colonial time for their everyday needs ranging from agricultural tools to household utilities. Local industries not only supplemented but also complemented agriculture and the people had enough to exchange with their neighbours for items, which they did not produce. The local industries thus enhanced trade and exchange between Esan and her immediate and distant neighbours before the coming of the British.

British calculation was that encouraging local industries would have been a negation of colonial economic objective as the need to provide outlets for British goods was fundamental to colonial endeavours. In this circumstance, the encouragement of indigenous industries was out of the question (F.J.D. Lugard, 1965, p.512). If any industry had to be encouraged, it had to do with improving the quality of raw materials to be exported from the colonies to serve the industrial needs of the metropolitan industries. It was expected that this would in time promote the commercial and industrial progress of colonies and their people (Ibid., p.510) This policy was aimed at breaking the economy viability of the colonies and subjecting them to a state of perpetual dependence on manufactured goods from Europe (Ibid.). ${ }^{3}$

The main interest of the British authorities in Nigeria therefore, was the maximization of profit and this came basically from the production of raw materials which were exported to Europe. There was no attempt at encourage local industry which would have made the people self-sufficient and economically independent. The only attempt at industrialization was the establishment of processing mills in some areas and these were to ensure that "raw materials are brought to the most finished state possible before export" (Ibid., p. 511). This was with the objective of increasing the value of the raw materials, avoiding waste in preparation, utilizing the byproducts, and decreasing bulk and thus, saving cost in transport both by land and sea (Ibid.). It was in this regard that a few mills were erected in some areas to crush palm kernels so as to secure a better quality and large saving in fright charges (Ibid.). Similarly, mills for the processing of groundnut were erected to reduce transport charges both by railways from the interior to the coast for export to Europe. Ginneries were also erected for separating lint from the seed of cotton while hydraulic presses were erected for packing the cotton to make it convenient for export. Saw mills were established for the processing of timber for export. The establishment of these simple industrial processes were meant solely to improve the quality of raw materials and reduce labour and transport charges and not with the objectives of enhancing the industrial base of the colonies. British industrialization policy was thus a challenge to the survival of nascent industrialization in Esan. We would examine these policies 
against the backdrop of local efforts to meet the demands of the British and at the same time sustain indigenous industrialization.

\section{Wood/timber industry}

Woodwork such as carving, had been a prominent profession in Esan before the established of colonial rule. Carvers produced items of utilities such as mortar (okor), pestle (obhi-okor), wooden grinding and eating bowl (uro), staff of office (ukhure) for the elders (edionwele) and kings (Enojie), stool, hair combs and different types of masks for masquerades (okpodu) and dolls for children and ancestral shrines among others. Some other items like doors, windows, stools, walking stick, wooden handles for farm implements such as hoes, cutlasses, knives and chisels were also produced by carvers. This industry flourished because of the availability of thick forest with abundant wood and timber. Apart from the raw materials, which the wood provided for indigenous industries, it also provided them with fuel in the form of firewood. The forest also provided the people with meat from all kinds of game, which they hunted.

The settlement pattern of Esan was such that the people lived in communities, which were separated from their farmlands. A village could possess vast forests and farmlands. The British authorities therefore, had the erroneous impression that most of the forests in the areas lacked ownership and so, were freehold (NAI., BenProf. B.P. 40/Vol.XIV, 1950). It was in this respect that they decided to take possession of the forest by granting license to foreign companies to exploit them and putting others under reserve thus depriving the people of their God-given resources. Various laws were enacted which empowered the colonial authorities to compulsorily create reserves, even when the communities did not support such exercise. The original owners of the forest were allowed to obtain timber from the forest only for their personal use but not for sale. Even areas outside the reserve, "protected trees" [timbers] could be obtained by the indigenous people but only with the authority of the colonial administrators.

So, the British found in Esan a vast and largely unexploited forest with different types of timbers. The first major attempt at exploiting the forest by the British authorities was to carry out a survey and enumeration of the forest to identify the various types of timbers therein. This survey revealed a large variety of timbers such as obeche, agba, mahogany, iroko, abura, among others; some of them with enormous girth. The next action was the creation of reserves and the demarcation of the reserved forest into compartments while leaving only a little for the people to farm. Trees in the unreserved forest and the areas where the farmers could farm were declared, "protected trees" and this meant that it was only by the authority of the colonial government that such trees could be exploited. The completion of this task was followed by the entry of foreign firms to whom the various compartments were 
allocated for exploitation. The firms included the United African Company (UAC), which got the bulk of the compartments, Messrs. I.T. Palmer, Nigerian Hardwood and British West African Timber Company. The companies began by constructing roads into the areas allocated to them for exploitation.

As mentioned earlier, in pre-colonial Esan as in other communities in what came to be known as Southern Nigeria the area where the people inhabited (villages and towns) were separate from where they farmed. Each village therefore had vast forest farmlands which were held in trust for the people by those in authorities such as traditional rulers and elders. However, individual farmers and families had a number of farmlands which they cultivated rotationally in the shifting cultivation system which they practiced. Apart from this, there were also virgin forests, some of which were far away from the villages. These forests served as hunting ground and avenue to obtain wood by local craftsmen. Individuals who had no sufficient farmlands could, with permission of these in authorities, cultivate portions of the virgin forest. So, the vast forests in Esan and elsewhere were not without owners as the British authorities had thought. Villages and communities knew the boundaries of their forests which were demarcated by natural and artificial means such as shrines. So, what the British found in Esan were not "freehold forests" but the ones owned by the villages and communities.

The British authorities therefore, had the erroneous impression that most of the forests in the Esan lacked ownership and so, were of freehold. It was in response of this that they decided to take possession of the forest - granting license to foreign companies to exploit them and putting others under reserve thus depriving the people of their natural resources. The original owners of other forest were allowed to obtain timber from the forest only for their personal use but not for sale. Even areas outside the reserve, "protected trees" (timbers) could be obtained by the indigenous people but only with the authority of the colonial administrators.

In the course of exploiting Esan forest, the companies did not contribute anything to the development of their areas of operation apart from the meager royalties, which they paid to the Native Authorities. In spite of the fact that the UAC controlled the bulk of the forest in Esan, it did not find it expedient to establish wood based industry in the area. Rather the company decided to establish a timber processing mill (saw mill) - Africa Timber and Plywood (A.T.\&P.) at Sapele - a town on the bank of River Ethiope - because of the economic advantage of closeness to the point (Atlantic Ocean) of exportation. Indigenous people who were interested in timber business were frustrated out by the Forest Ordinance which was enacted to give exclusive right of the forest to the British firms. The people were no longer allowed free access to exploit timber from the forest (whether reserved or unreserved) for their domestic use without obtaining "permit" as the timber in such forest were regarded by Forest Ordinance as "protected trees" (NAI, BenProf CSO/26/2/ 14617 
Vol. XIII, 1938, pp.20-22). Those who violated the order were prosecuted. By 1938 a number of people were prosecuted for "violating" the Forestry Ordinance. So, the people had to obtain license or permission to cut trees for local use. This invasion of the forest by these foreign firms thus led to the people's awareness of the economic value of the trees in the forest in their locality and so, they began to agitate for participation in the exploitation of timbers from their forest. As reported by Mr. Gray, a Senior Assistant Conservator of Forest in 1938; "there is no doubt that in Ishan, forestry is now 'known'. It is talked about, our policy is realized and more than one chief has expressed regret that he did not know the value that lay in his trees before it was too late." (Ibid, pp. 22-23). The exploitation of the forest without any benefit to the people and communities caused a lot of disaffection in Esan and so, they began to question the takeover of their forest by foreign firms. As they could not fight the colonial authorities because of the enormous powers of the "colonial police", they began to take it out on the traditional rulers and the chiefs who constituted the Native Authorities. They accused members of the Native Authorities of siding with foreigners to exploit them. They felt that the coalition between the traditional rulers and the foreign firms in the exploitation of the forest tended to put the money which would have gone into public use into the pockets of a few privileged members of their community who were members of the Native authorities. Members of the Native Authorities were therefore very unpopular as the people believed that "no agreement with such foreign firms could be profitable for the people and the Native Authorities" (BenProf. CSO 26/2 14617 Vol. XIV, 1948). Esan people began to agitate that they be allowed to participate in timber extraction. They accused members of the Native Authorities (some of whom were non-Esan) of compromising themselves by granting concession for the exploitation of the forests only to foreign firms to the detriment of the indigenous people.

The private bargaining for consents with members of the Native Authorities tends to put money which should go to public funds into the pockets of a few... The feeling against 'exploitation' by foreign firms has led to a general belief that no agreement with such firms can be profitable for Native Administration (Ibid).

The colonial authorities justified their total reliance on the foreign firms by saying that the indigenous people, whom they derogatory described as "small men", lacked the technical ability and financial capability to participate in the exploitation of the forests.

The desire that extraction shall all be done by Nigerian, and preferably men of the area concerned, is natural, and in time will be economically possible, but at present, the small men have not the

Copyright (C) IAARR, 2015: www.afrrevjo.net

Indexed African Journals Online: www.ajol.info 
technical knowledge, the mechanical equipment, and the access to world market, that the bigger firms possess (Ibid.). ${ }^{13}$

It was in order to douse this agitation and prevent a situation that could disrupt their economic interest that the colonial authorities set up "Forest Committees" in areas where timbers were being extracted (Ibid). These committees were made up of members of the native Authorities and those that the British officials considered as "opposition". The committees were expected to meet regularly and with the assistance of the District Officers and Provincial Forest Officer, to advice the Native Authorities on the best method of utilizing forest resources in Esan. However, as a result of the insincerity of the British officers, most especially, the District Officer, the committees rarely met and so, the objectives for which they were set up were defeated and the exploitation of the people went on unabated (Ibid).

As the agitation for active participation in forest exploitation continued, the colonial administration, rather than grant timber license to the people of Esan, began to issue same to non-Esan, most especially Benin chiefs who were working on behalf of foreign firms, like the UAC. In a letter dated April 11, 1938, to the Enigie who constituted the Native Authorities in Ubiaja, Uromi, Irrua, Ekpoma, Udo, Ugbegun, Igueben and Opoji, the District Officer introduced one Mr. Ihamah (a Benin) to them as a contractor to the UAC who had been granted license to exploit protected trees in Esan thus: "the bearer of this note, Mr. Ihamah of Benin City is the applicant who recently approached you for a license to cut protected trees in Area 23 which covers part of your clan" (BenProf. B.P. 1392/13, 1938) p.33). In order to pacify the people, they added that the license granted to such individuals or companies did not preclude the indigenous people from obtaining timbers from the forest for their domestic use but only under certain conditions.

A license does not prevent a member of the clan from taking a tree for his own use but if a farm is to be made in land upon which a valuable tree is standing which the farmer wishes to fell he is expected to ask the licensee to come and fell it. If the licensee does not do this within 3 months then the farmer may fell it himself provided it is not first class of course (Ibid).

In the reserve, the indigenous people were disallowed from felling trees and farming but the foreign companies were given free hand to operate in them. In fact, the UAC and the colonial authorities entered into an agreement which gave exclusive rights to the company to exploit forest under its concession in Benin Province which include Ishan Division, for a period of 32 years that was from 1945 to 1977! Similar agreements were signed with Messrs Hardwood Ltd and British West African Timber Company Ltd. (CSO/26/2 14617 Vol. XIII, 1948, pp.13-14). In fact, the UAC controlled an area of 87 square miles of forest as their logging allocation during the 
period 1945 to 1955 (CSO/26/2 14617 Vol. XIII, 1948, pp.9-10). In spite of the abundant timber in Esan, the British authorities did not find it expedient to establish wood based industry in Esan. Before the arrival of the British as mentioned earlier, wood based industries had flourished in Esan. One would have expected the British to sustain these industries but they refused. However, establishing industries would have defeated the primary objectives of colonialism. The British were more interested in preserving Esan and other parts of Nigeria as large markets in which they would obtain raw materials needed by industries in Europe and for the disposal of finished products from Europe. In line with this objective, they preferred to extract wood in logs for semi-processing at their timber factor at Sapele before shipment to Europe.

The only aspect of wood exploitation in which the people could be said to have "benefited" was in area of employment as unskilled labourers who were engaged in clearing roads in the forest, felling of trees and cutting them into logs with axes and helping to load them into vehicles. By 1948, the major timber exploiting companies in Benin Province had in their employment about 3,000 labourers (BenProf, 1948 Annual Report, pp.13-14). These labourers were however, poorly paid and provided with deplorable accommodation. In fact, the boom in timber in the 1940s and 1950s did not positively affect the workers as they were in some cases treated as slaves and bondsmen who must necessarily be tied to their employers no matter the condition of work. In some cases, their salaries were not paid or deliberately delayed to prevent them from seeking employment.

The relatively prosperity of the timber industry has attracted many contractors without sufficient capital. This, no doubt, has been mainly responsible for the numerous complaints of non-payment of wages to labours employed in the industry. The usual excuse for late payment of wages has been that logs have not been sold. Some contractors withheld the wages of their labourers to prevent them moving en-masse to other areas where better condition obtained (BenProf CSO/2 14617 Vol. XV, 1949, p.31).

In the area of employment, Esan people did not benefit from the timber industry. This was because the bulk of the labourers that these timber companies employed were migrant labourers mostly of Igbo origin. The companies prefer to employ these migrant labourers because they were ready to receive whatever wages they were paid unlike the indigenous people who were not willing to receive low wages for hard labour. This point was emphasized in the 1949 Annual Reports of Benin Province: "Between 2300 and 2800 labours are employed by European firms on timber exploitation... These labourers are mostly Ibo strangers who seek temporary employment for a few months in order to acquire a few pounds cash" (Ibid.). 
There is no way of knowing the number of trees extracted from Esan forest as the colonial authorities and the foreign firms did not keep accurate records. It was only in 1948 that the District Officer reported that 20,000 trees were felled in Benin division. The main reason for this lack of record was that the companies allotted part of the compartments to indigenous contractors to extract timbers on their behalf. These indigenous contractors were not very good in keeping the records of the number of trees they extracted from the forest. The companies were also in the habit of manipulating record of timber extracted in order to evade the payment of fees and royalty to the Native Authorities. So, in 1948 a total of 20,000 trees were said to have been felled in Benin Division in which the Native Authorities derived royalty and fee of $£ 98,888$. This then amounted to $£ 4: 9 /-$ per tree. In Benin Division also, the fees and royal obtained in 1949 was $£ 72,952$. When this is divided by $£ 49 /$ - it would mean that about 14,888 timbers were extracted from Benin forest in that year. Comparative figures of forest revenue (fees and royalties) from other divisions of the Province, including Esan is as follows:

\begin{tabular}{|l|l|l|l|l|l|l|}
\hline & $\begin{array}{c}1948 \\
£\end{array}$ & $\begin{array}{c}1949 \\
£\end{array}$ & $\begin{array}{l}1950 \\
£\end{array}$ & $\begin{array}{c}1951 \\
£\end{array}$ & $\begin{array}{l}1953 \\
£\end{array}$ & $\begin{array}{l}1954 \\
£\end{array}$ \\
\hline Asaba Division & 10,696 & 14.917 & 13,748 & n.a & 10,933 & n.a. \\
\hline Ishan Division & 4,935 & 7,809 & 10,678 & 6,878 & 6,978 & 35,000 \\
\hline $\begin{array}{l}\text { Kukuruku } \\
\text { Division }\end{array}$ & 355 & 927 & 1,085 & n.a. & 1,085 & n.a. \\
\hline
\end{tabular}

Sources: N.A.I., BenProf Annual Reports: 1950, pp.29-30; 1951, pp.6-7; 1954, pp.6-7.

From the above figure, the revenue derived by Ishan Native Authority was $£ 4,935$ in 1948. If this is divided by the amount (£4: 9/-), it would mean that only about 1007 trees were extracted from forest by all the companies operating in the area in that year. If this was the case, it was not have necessitated the glee with which the District Officer described timber business in Esan in the same year; "Except in Kukuruku Division, the big money is now being ... made in timber" (Ibid. p.5). The big money being made in Esan would not have come from about 1007 timbers in which the Native Authority only derived $£ 4,935$. It is in this regard that we have reason to believe that the number of trees extracted in Esan was grossly underestimated.

Colonial apologists are quick to claim that the people derived a lot of benefit from the exploitation of timbers in their area. This was hinged on the number of equipment being poured into Esan and the roads and bridges which were constructed through the forest by companies. According to 1949 Annual Reports: "tractors and vast trucks with trailers appear all over the places...even heavy road graders are seen smoothing highways through the bush" (Ibid., pp. 5-6). There is no doubt that tractors 
and trailers including road graders were poured into Esan but the question one would ask is on whose benefit were these equipment imported and roads constructed. The answer to the question is that, it was certainly not in the interest of the people that this equipment were imported and roads constructed through the forest, but the interest of the foreign firms. The firms needed the equipment to facilitate maximum exploitation of timbers in the forest and the roads to evacuate these timbers to the point of exportation. Apart from facilitating maximum extraction of timber, mechanization also enabled the companies to reduced the number of unskilled labourers and thus maximum profit as could be seen in the 1948 reports by the District Officer, Ishan Division,

Except in the Kukuruku Division the big money is now being made in timber. To judge by the capital being poured into Sapele and into the forest area by African Timber and Plywood Limited [owned by U.A.C].... Tractors and vast tractors with trailers appeared all over the places; two logging ports are being erected in the Benin Division, each with crane and steel-faced wharf; even heavy road graders are seen smoothing highways through the bush (Ibid, p.30).

There was certainly no evidence that "big money" and "the capital being poured... into the forest area by A.T. \& P." in Esan and elsewhere benefited the people directly. The mechanization of timber exploitation, which necessitated the use of tractors and trailers, did not amount to the development of Esan. This equipment was solely provided to enhance the effective and maximum exploitation of the forest. This processes invariably led to reduction of workers by the companies as machine now provided the labour, which hitherto had been performed by man. By the use of these machines, the companies could extract complete tree-length timbers directly from the forest which were carried by these trailers to Sapele waterside where they were logged for floating or barging to Sapele saw-mills (BenProf. B.P. 40/Vol.XIV, 1950, pp.29-30). This process, in as much as it profited the companies, had negative effect on the people as the companies had to reduce the number of their unskilled labour as much as half between 1946 and 1950 (Ibid.). According to 1950 Annual Report: "The process of mechanization, which became noticeable in 1949 has been intensified... for instance the unskilled labour force has been reduced by more than half" (Ibid.).

This was at a time when a large number of timbers were being exploited from the forest and the foreign timber firms; African Timber and Plywood Limited and British West Africa Company were working at full capacity whereas the area in which the timbers were being obtained was witnessing neglect and unemployment:

The mills in Sapele are both working to capacity principally with timber from this Division and extraction within the concession areas will have to be stepped up to meet the demands of Sapele mills. 
British West Africa Timber has ordered a new sawmill at Sapele, to be supplied entirely with Benin Timber (Ibid).

So, the process of mechanization rather than brought development to the people of Esan and other timber producing areas, further helped to pauperise them. The only beneficiaries were the timber companies and their owners. The same can be said of the roads, which were constructed in the forest. These roads were not put in place for the benefit of the people but for the effective evacuation of timbers from the forest. This conforms to the view by Crowder that the benefits which the people may have derived from colonial rule were not intended but accidental,

Under colonial rule any economic benefits that may have accrued to the African results from accident not design, by products of the primitive economic system the colonial powers to carry from Africa its raw materials for processing in the factories of Europe, in exchange for the strictly limited range of European manufacturers. The principal beneficiaries were the stockholders of the companies importing and processing the raw materials, and those that produced the goods exported to Africa in exchange... and of course the materials for the development of the transport system that could facilitate the economic regime (M. Crowder, 1981, p.274).

\section{Cloth weaving}

As earlier mentioned, the colonial authorities were not ready to encourage local industries in Esan and elsewhere. They saw the colonies as a big market from which to obtain raw materials and dispose their finished goods. As a result of this, they did everything possible to either kill or discourage local industries so that the market for their finished products could flourish.

One of the major casualties in this regard was cloth weaving industry in Esan. This was one industry in which Esan were renowned. The industry derived its raw materials from the species of cotton which is said to be indigenous to the area and known "Ishan Cotton" (G. vitifolium). This species was widely cultivated in precolonial Esan. It had long, strong and coarse lint which was used for weaving "Ishan Khaki" - a thick loin multi-coloured cloth (ukpon ododo) (Okojie, 1994, pp.15-17). Weaving of this type of cloth was one of the most important crafts carried out by the women in Esan using the vertical hand loom. The production of ukpon ododo was widespread in Esan. Every household in pre-colonial Esan is said to have at least one hand loom. The cloth produced in Esan was popular and it was one of the main articles used for exchange with their immediate and distant neighbours. Esan cotton cloth also found its way to Europe at about the fifteenth century through trade contact between Bini and the Portuguese (Ibid.; Izuakor, 1987, pp. 34-35; N.A.I., 1982, p.xix). 
In order to undermine this industry, the British decided to massively import cheap and low quality textile materials into the country. By this, they were set to achieve certain objectives. The first was to reduce the patronage of locally produced cloth which was superior to the imported version. The second was that reduced patronage of locally produced cloth would make production of local cloth unprofitable. This in turn would lead to a decline in the patronage of locally produced cotton lint. The non-patronage of locally produced cotton lint would provide enough for export as British were already worried that boom in local cloth industry was having negative effect on their ability to purchase enough cotton for the Lancaster industries. According to Lord Lugard; "... imported cloth, if cheap and strong, decreases the demands for raw cotton for local weaving" (Lugard, 1965, p.523). However, the First World War and its aftermath, gave the textile industry some respite. This was because the economic depression that followed the War gave rise to high cost of imported goods including textile products. As a result of this, the people could no longer afford to purchase imported cloth and so resorted to the locally produced ones and this once again gave fillip to local textile industry in Esan. To meet this high demand, women intensified the production of locally produced cloth and they derived a lot of benefit from the sale. It was in the course of these period that excellent specimen of Esan textile materials were sent to the British Empire Exhibition which took place in 1923 where they were displayed and attracted a lot of admirers who demanded for the materials (N.A.I. Intelligence Report,1982). It was to satisfy this demands that textile industries in Britain began to produce imitation of Esan cloth which they exported to Nigeria. At the initial stage, the people were not ready to patronize these cheap and low quality imported textiles. However, the outbreak of the Second World War led to difficulties in importing goods to the colonies and this once again revived Esan cloth industry. As the European administrators could no longer import all they needed for both civilian and soldiers in the colonies, they had to resort to local products most especially, Esan textile materials. Like the case of cash crops, women and school children were encouraged to produce whatever items would help the Allied Powers to win the war. As Esan had been known to be good cloth weavers, the colonial authorities had to resort to them to meet some of their textile needs. In 1941, they placed orders for the supply of a number of items such as strings and table tennis nets among others from Esan and this once again kept textile industry in Esan busy;

In Ishan, local industries flourished. The Ubiaja cloth industry was kept very busy by large orders from Lagos. String is made in many schools, the post office being a buyer. The makers of tennis nets in the Roman Catholic School, Ubiaja have been kept busy...(BenProf CSO 26/2 14617 Vol. XIV, 1941, p.16). 
In 1942, the colonial government in Lagos bought 960 hanks of bagging twine and over 22,000 strip of cloth (9ft by 28 inches) from Esan. They also bought more than 50,000 string dusters (Ibid.). The rice mill at Ekpoma which was established in 1942 also depended on local producers for its sack requirement (NAI, BenProf. Annual Reports, 1941, pp. 11-12; NAI BenProf Annual Report, 1942, p.9). In 1942, alone, the mill obtained more than 1,000 locally produced sacks. Until the end of the war, the textile industry in Esan was able to meet the demands of the local people as well as the demands by the colonial authorities.

At the end of the war, the colonial authorities made effort to encourage a lot of people to go into textile production. This was due to the scarcity of textile products in Nigeria even after the War. This scarcity was necessitated by the slow pace of recovery of textile industries in Britain and other European countries. As quantity of textile materials imported into the country at the end of the war, could not meet the need of the people, the colonial authorities decided to look inward. To this end, a Textile Training Centre was opened at Auchi - Esan's northern neighbouring town with its first intake commencing training on August $1^{\text {st }}, 1948$. The colonial Governor officially opened the centre on September $20^{\text {th }}, 1948$. The centre was devoted to training of men in weaving and dyeing and was expected to train students from all over Benin Province who, on completion of their training were expected to set up their own loom at home (BenProf, 1949 Annual Report, p.30). Although there was no difficulty in obtaining men for training, the colonial authorities were to realize that the objective for which the centre was set up was not being achieved. This was because the trainees, on graduation abandoned the job immediately they passed out of the centre, as none of them was ready to set up a loom at home. By 1950, it was becoming obvious that the centre was not having any positive effect on textile industry in Esan and other part of the Province.

The Senior District Officer, Kukuruku Division, reports disappointing result of the Auchi Textile Centre, which has little effect on the standard of local weaving - already satisfying local demands and does not seem to provide training which encourages many of its pupils to set up in business when they leave (BenProf 1950 Annual Report, p.27).

One measure taken by the colonial authorities to overcome these difficulties was to set up Divisional Weaving Centres in each of the four Divisions of the Province which would cater for the graduates of Auchi Textile Centre. These Centres were to be equipped with looms and other weaving equipments and to employ some of the graduates from the training centre to manage them. These graduates were to be put on fix salaries to encourage them to stay. In 1952, a central weaving centre known as Provincial Weaving Centre was also opened by the colonial authorities at Auchi 
and it employed some of the graduates of Auchi Textile Centre. The other graduates who were mostly from the other Divisions [including Esan] who could not secure employment at the centre went back to their villages to continue with their previous vocations. The impact of the Training Centres was therefore not seriously felt in Esan and elsewhere outside Auchi. The main reason for its failure was that it focused on a wrong target - male students. Traditionally, Esan men were not involved in cloth weaving. The occupation had always been that of the women. To ask men to train as cloth weavers and then establish looms in their villages was an exercise that was destiny to fail. So, when the training centre was opened solely to train boys, the proprietors would have known from the outset that it would not work. One thing was certain, even if it had been established to train women it would only have attracted those from the location of the Centre. No family would have sent its daughter(s) from Esan to Auchi for training. Also, even if the ex-trainees had established looms, they would have witnessed low patronage as British merchants had flooded the country with cheap and inferior textile products. Although the Auchi Textile Centre still exists till date, it has not grown beyond what it was during the colonial period. The abhorrence of men to train as clothe weavers and the massive importation of cheap and inferior textile products combined to abridge the development of textile industry in Esan. As one of the colonial officials lamented,

[u]nfortunately, this industry has now been allowed to die due to the abundance of cheaper and more mass-produced textile materials of all types. The famous khaki cotton grown by the Ishan people has disappeared partly due to the exhaustion of the soil and partly due to lack of demand following the abandonment of weaving (N.A.I., Intelligence Reports, 1982, p.xix).

Although cloth weaving is still being practiced in some Esan communities such as Ewatto, Ebelle, Emu, Ohordua among others, the products are only being patronized by a few wealth individuals who require them for certain traditional ceremonies such as age grade initiation, marriage and burial as well as taking of chieftaincy titles.

\section{Pottery}

Pottery was one of the industries that flourished in Esan before the arrival of the British. It was an important household engagement in which Esan women were highly involved. Women in some Esan communities such as Ewu, Ibore, Uzea, Idegun in Ugboha among others were noted to have produced high quality household ceramic products. The raw material - clay - was dug from the clay holes in some of the streams in their localities. Pottery products of different shapes, sizes and for different purposes were produced by the women. The British officials on their first arrival at Esan were impressed by the quality of pottery and other ceramic products which were produced

Copyright (C) IAARR, 2015: www.afrrevjo.net

Indexed African Journals Online: www.ajol.info 
by the people. At the initial stage, they patronized the industry by purchasing its products for use at home and offices mainly as decorative. Towards the late 1930s, the British officials began to show some interest in ceramic industries as they could not import all their ceramic requirements from Europe due to the outbreak of the Second World War. So, the local producers enjoyed a period of relative boom but immediately after the War, European merchants began to import iron and other ceramic products into the country. However, by 1950 interest in local ceramic industry was again revived when a pottery officer, Mr. Michael Cardew was sent to Benin Province to assess the pottery and ceramic potential in the area (N.A.I. BenProf 40/Vol. XIV, 1950, p.27). In the course of his tour, Mr. Cardew found a lot of kaolin deposits in different parts of the Province. He was also impressed by the quality of local ceramic products and the potentiality of exporting kaolin most especially from the Kukuruku Dvision. He then recommended the establishment of Pottery Training and Experimental Centre in Benin City (Ibid.). However, the British authorities did not see the need to implement this recommendation which would have benefited the people. As one of their main objectives was outlet for British merchandise, they did not see what it would benefit the British entrepreneur if pottery industry was developed in Esan and elsewhere. They therefore preferred the importation of iron and aluminum utensils as against locally produced ones. This situation eventually led to the gradual decline of pottery industry in Esan and elsewhere in Benin Province.

In spite of this however, the industry has survived as a few people still preferred locally produced ceramic products in certain areas such as aesthetic, traditional worship and sacrifice. Ceramic products are also used to serve local delicacy known as pepper soup in some restaurants due to their ability to retain heat for a longer time. However, most people now prefer to use iron, aluminum and plastic utensils as against locally produced ceramic products.

\section{Soap industry}

Another industry that has also suffered under colonial dispensation is that of soap production. The raw materials for the production of soap were palm oil and ashes from burnt wood and banana leaves. These were mixed with water and allowed to boil over fire until the water had completely evaporated leaving a black substance known as ebakho - the native soap. The soap was used for all activities that require cleaning such as bathing and washing of clothe and cooking utensils. In pre-colonial period, the production of this soap was widespread not only in Esan but the whole of what is today Southern Nigeria. It was therefore one of the main items of exchange among the people.

The activities of the British colonial masters and trading companies seriously undermined this vital industry. In order to better their economic interest, foreign trading companies began to import large quantities of soap and detergent into the 
Esan and other part of the country. They therefore adopted different method and propaganda to discourage the use of locally produced soap. The people were discouraged from the use of locally made soap to wash the imported fabric as this would, according to the colonial officials, negatively affect their texture and colour. Instead, they they were advised to use imported soap and later detergent to wash imported textile materials to ensure their durability. As the people would not want their "expensive" fabric to fade or go bad, they had to abide by the advice of the colonial officials and merchants not to use locally made soap to wash them (Osagie Ogbeide 1987, Ighalo Obakhan 1987, Md Aimierobiye Ogbeide 1987, Oamen Iregbeyen, 1987). As more people began to patronize imported soap, the expansion of local market which would have had positive effect on indigenous soap industry did not materialise. So, the industry suffered gradual decline to the extent that as today, it is only in existence in isolated areas as its products are only being patronized by traditional doctors to treat certain skin diseases.

\section{Palm wine production}

Palm wine was the main alcoholic beverage produced in pre-colonial Esan. Palm wine tapping was not a major industry but was carried out by some individuals mainly on part-time basis. The wine was obtained from tapping matured palm trees most of which grew wild in the forest. The coming of the Europeans necessitated high demands for palm produce - oil and kernel. Since the early nineteenth century, as a result of Industrial Revolution, these products were in high demands in Europe. While palm oil was used as lubricant for machines and ingredient in the production of soap and candle, palm kernel was a major ingredient in the manufacture of margarine and livestock feed. Between 1900 and 1960, the quantity of palm oil exported from Nigeria rose by over five fold from 85,624 tons in 1900 to 418,196 tons in 1960 (G.K. Helleiner, 1966, pp. 506-507).

With the colonization of Esan, the people began to produce large quantities of palm oil and kernels which were sold to the foreign trading companies for export to Europe. The outbreak of the Second World War led the high demands for palm produce in Europe and the colonial authorities had to mount heavy propaganda to urge the people to embark on massive production these products. Thus, palm trees in the forest and later in the plantations became valuable and the colonial authorities discouraged the tapping the trees for palm wine as the trees that were subjected to tapping would no longer produce palm fruits. So, although there was no specific legislation to prevent the tapping of palm trees, the people on their own preferred to preserve them so that they would yield palm fruits from which palm oil and kernel were derived (Ibid.). So it was only a few palm trees, most especially those within the villages that were tapped for palm wine. Another reason for the near abandonment of palm tapping in Esan was that the labour associated with the production of cash crops 
especially rubber was intensive and time consuming. As a result, the people concentrated their energy on the production of cash crops while abandoning other subsidiary economic activities such as palm wine tapping. As a result of its short supply of palm wine in Esan, the prices of the ones available in the market went up. In order to capitalize on this, some enterprising individuals, mostly Igbo migrant Igbo at Ebelle, a town in the south west of Esan took up the challenge of producing palm wine as their main economic activity (Ibid.). These people began to tap the palm trees in distant locations which were not harvested mainly due to the difficulties of conveying palm fruits through long distances (Ibid.). The palm wine so tapped was initially sold within their community or conveyed by bicycles to markets in neighbouring towns such as Ogwa, Ewossa and Ugun. Subsequently, restaurant and bar owners in the emerging urban centres in Esan such as Ekpoma, Ubiaja, Uromi and Irrua began to travel to those towns on their market days to buy palm wine for sale to their patrons.

During the course of the Second World when the prices of imported goods, including alcoholic drinks, went up most people among including urban dwellers began to patronize palm wine as it was readily available and cheaper than the imported drinks. To meet the demand of these urban dwellers, restaurant and bar owners began to travel daily to Ebelle buy palm wine directly from the producers As a result of this, palm wine tappers at Ebelle no longer conveyed their products to markets in neighbouring towns to sell as the buyers now flock the town daily in search of palm wine. With increase in patronage and its attendant financial returns, some indigenous people also went into palm wine tapping. As time went, the town, Ebelle began to be associated with good palm wine and most people began to demand for "Ebelle Wine" in all traditional ceremonies such as marriages, burial, investiture among others (Ibid.). Up till date, the demand for "Ebelle Palm Wine" is still high among Esan people and no traditional ceremony is complete without it.

\section{Rubber processing}

The colonial authorities did not make any effort aimed at establishing rubber processing factory in Esan in spite of the large volume of rubber produced in the area (J.I. Osagie, 2004, 87-105). Rubber latex was processed into "lump" and "sheet". However, Lump did not need mechanical processing; all that was required was for the latex to be collected at about twenty-four hours after tapping, into a bowl or bucket. Little quantity of coagulated acid was thereafter added to it. After a few hours, the latex would form a lump and this was extracted from the bucket and thereafter taken to the buying station for sale. As rubber lumps produced in Esan usually contained some impurities such as pieces of wood and sand, the prices for which they were sold were usually low. Rubber "sheet" on the other hand, attracted high prices but required some mechanical processing. To produce the rubber sheet, the farmers required some 
rectangular containers obtained by cutting kerosene (rectangular) container vertically into two equal halves. The latex for the production of rubber sheet had to be in liquid form and free of impurities. This liquid was collected a few hours after tapping when it had not coagulated into the containers up to about one inch full and a little coagulated acid added to it. This means that the taper had to have a number of such containers as each container required little quantity of latex. The latex was allowed to coagulate in the container for about two days to form what was locally known as rubber sheet. When the sheets had been removed from the containers, "hand pressing machine" was used to extract water from them thereby leaving what would look like a foot mat. The rubber sheets were then kept in the sun for several days to dry after which they were packed and sent to the buying station for sale.

In Esan, there were a few rubber-processing machines and these were owned by rich farmers with large rubber plantations. The generality of the farmers and tappers had to depend on these machines for the processing of their rubber sheet for a fee. The farmers who were based in the remote villages and other communities where there were no pressing machines and those who could not effort pay for the services of these machines produced only rubber lump. Considering the volume of rubber produced in Esan, one would have expected the colonial authorities to provide pressing machines or establish rubber-pressing centres to ease the job of the farmers and tapper. So, the farmers had to go through a lot of difficulties including having to invest huge sum of money in the purchase of pressing machine for the processing of their rubber products which in the end were solely met for export to Europe. The colonial authorities were only interested in getting rubber for export without taking into consideration, how they were produced or the difficulties which the farmers encountered in the course of production.

It was also expected that the colonial authorities would have established a factory in Esan to process the rubber lump and sheets before exporting. If this was done, it would have helped to develop the areas in which the rubber products were obtained. The colonial authorities did not consider this, as they were only interested in exporting raw materials for primary and secondary processing in Europe. So, it was not until 1954, when the process of decolonization had fully commenced that the Western Regional Production Board established a rubber-processing factory besides Ikpoba River in Benin, a distance of about 70 kilometers from Esan. The factory which commenced production in 1955 was said to be the largest of its kind in the world at the time (BenProf B.P. 40/Vol. 18, 1954, p.20). With the establishment of the factory, all the rubber lumps produced in Benin Province were sent to Benin City for primary processing before being exported to Europe. So, in spite of the large quantities of rubber produced in Esan during the colonial period, the people did not benefit from any rubber-based industry financed by the colonial authorities.

Copyright (C) IAARR, 2015: www.afrrevjo.net

Indexed African Journals Online: www.ajol.info 
Apart from the above, other industries that had existed in Esan before the coming of the British either suffered lack of patronage or total decline. One of such was basket and mat weaving which suffered lack of patronage as most people now patronized imported substitute such as plastic, aluminum and iron items of utilities. Blacksmithing which had been a major occupation in Esan also witnessed a gradual decline as European merchants imported iron cutlasses (opia), knives (ukpoghae) and hoes (egue) - items which indigenous blacksmiths (ogiogun) had hitherto fabricated. Although blacksmiths and other indigenous craftsmen/women still practiced their trade today, they now have a few patrons who are mainly rural dwellers and those who require their products for either for aesthetic or traditional ceremonies and worships.

\section{Conclusion}

The British authorities were not unaware of the industrial potentialities of Esan and elsewhere in Nigeria. The rudimentary experiment of local industries during the Second World War showed that the people possessed the necessary potential for rapid economic development but all they (the British) were interested in was to enhance their industries at home (Lawal, pp. 114-117). In this regard, they introduced a number of policies, which ensured that Nigerians depended on them perpetually for manufactured goods from Europe. No effort was made either in the short term or in the long term, aimed at encouraging the various indigenous industries in Esan. They however, contemplated that in the course of exploiting the colonies, a time would come when the people would "desire to manufacture for themselves, instead of remaining dependent on the factories of Europe, as they had seen that Africa was capable of becoming an efficient and capable skill entrepreneur (Lugard, 1965, p.509). To them, "in the natural evolution of industrial progress, a country begins by exporting raw materials in exchange for manufacture goods, later improving its exports by better preparation and semi-manufacture, and finally becoming itself a manufacturing community (Ibid.). True to these principles, the people for several years were compelled to produce raw materials were processed locally mainly to reduce weight and cost of transportation. It was in this regard, that rolling machines were imported to process rubber to reduce weight and eliminate impurities and sawmills to process timbers before being exported. However, the British deliberately did not work towards a time when the people of Esan or Nigeria would become "a manufacturing community" in spite of the fact that based on the abundant raw materials in Esan and elsewhere, Nigeria had the necessary potential for industrialization. Rather, they neglected or out rightly conspired against the industrial potential of indigenous people, preferring to reserve Esan and other Nigerian communities mainly as a big market for imported goods - a situation that would benefit industries and people in the mother country. 


\section{References}

Bradbury, R. E. (1957). Benin Kingdom and the Edo speaking peoples of Southwestern Nigeria, London: International African Institute.

Crowder, M. (1981). West Africa under colonial rule, London: Hutchinson

Helleiner, G.E. (1966). Peasant agriculture, government and economic growth in Nigeria, Illinois: Richard Irwin Inc.

Izuakor, L.E. (1987). Pattern of pre-colonial exploitation. In T. Falola (ed.) Britain and Nigeria: exploitation or development? London: Zed Books.

Lawal, A. A. (1987). Industrialisation as tokenism. In T. Falola (ed.), Britain and Nigeria: exploitation or development? London: Zed Books.

Lugard, F.J.D. (1965). The dual mandate in British tropical Africa, London: Frank Cass.

Okojie, C.G. (1994). Esan native laws and customs with ethnographical studies of the Esan people. Benin City: Ilupeju Press.

Osagie, J. I. (2004). Economic development in Esan in the colonial period. Unpublished Ph.D. Dissertation, University of Benin, Benin City, Nigeria.

\section{Intelligence Reports}

National Archives, Ibadan, (N.A.I), B.P.40/Vol. VI, Annual Report on the Benin Province for 1937.

N.A.I., Benin Province (BenProf.) CSO/26/2 14617 Vol. XIII, Annual Report on the Benin Province for 1938.

N.A.I., BenProf. B.P. 1392/13: G.G. Harris, Acting Resident, Benin Province to the Senior Assistant Conservator of Forests, Ubiaja Circle, "Application for a Timber License for Area No. Benin 23, in the Ishan Division by Mr. G.O. Ihamah, dated 11 April, 1938.

N.A.I., BenProf. Annual Reports on Benin Province for 1941.

N.A.I. BenProf. CSO 26/3/14617, Vol. XIV, Annual Reports on the Benin Province for 1942.

N.A.I., CSO/26/2 14617 Vol. XIV, Annual Report, 1946, Benin Province.

N.A.I., CSO/26/2 14617 Vol. XIII, Annual Report, 1948.

N.A.I., BenProf. CSO 26/2 14617, Vol. XIV, Annual Report, 1948, Benin Province.

N.A.I., BenProf. Annual Report, Benin Province, 1948. 
N.A.I. BenProf. CSO/2 14617 Vol. XV, Annual Report, 1949, Benin Province.

N.A.I.,BenProf. B.P. 40/Vol.XIV, Annual Report Benin Province, 1950.

N.A.I. BenProf. B.P. 40/Vol. 18. Anuual Report, Benin Province, 1954.

National Archives of Nigeria (1982), Intelligence Reports on Ishan Division of Benin Province, Ibadan: National Archives.

\section{Interviews}

Interview with Osagie Ogbeide, 74, Farmer, Emaudo Ekpoma, 8-6-87.

Interview with Ighalo Obhakhan, 64, Farmer, Emaudo Ekpoma, 11-6-87.

Interview with Madam Aimierobhiye Ogbebor, 80, Farmer, Irrua, 9-7-87

Interview with Oamen Iregbeyen, 67, Farmer, Iruekpen Ekpoma, 13-6-87. 